\title{
Impact of Thiadiazole as Bombyx Mori Growth Enhancer
}

\author{
Neha Singh Sisodia ${ }^{1}$ and S. Gaherwal ${ }^{2} *$ \\ ${ }^{1,2}$ Department of zoology, Govt. Holkar Science College, Indore (M.P.), India
}

Available online at: www.isroset.org

Received: 13/Mar/2019, Accepted: 15/Apr/ 2019, Online: 30/Apr/2019

\begin{abstract}
Sericulture or silk farming is the rearing of silkworms for the production of raw silk. The mulberry silkworm, Bombyx mori is a domesticated and monophagous insect which feeds only on the leaves of mulberry for its nutrition. In this study we investigated the growth and economic parameters of Silkworm, Bombyx mori (Lepidoptera: Bombycidae) by dietary supplementation of thiadiazole. Thiadiazoles are heterocyclic compounds containing oxygen and nitrogen. 1, 3, 4, thiadiazoles are extensively studied and are known to play diverse biological activities. Diamines or polyamines are found in various biological fluids and are necessary for optimal growth, replication and metabolism of every cell in the body. This report describes the synthesis of diamino substituted thiadiazole and its effect on the growth parameters of Bombyx mori silkworm. Results show that the thiadiazole resulted in increased worm weight, silk gland weight and cocoon weight. We conclude that the thiadiazole can be fed to Bombyx mori silk worms for improving their economic parameters.
\end{abstract}

Keywords: Diamines, Thiadiazoles, Bombyx mori, sericulture, Economic parameter.

\section{INTRODUCTION}

Sericulture is one of the agro based industries in India. India occupies second place of Mulberry raw silk production in the world. Mulberry silk comes from the cocoons of Bombyx mori $(L)$. The fact that the Silkworm, Bombyx mori is domesticated for nearly four thousand years ago is well established. It is well documented that all insects require proper environmental conditions for normal life [1]. The environment influences the activities of the organism directly or indirectly. This is true for domesticated insects like Bombyx mori. Due to continuous domestication for many years, the silkworm has lost many of its natural activities as sense of smell, flight etc. and it is completely under the protection of the silkworm growers [2]. Though the number of generations in a year is controlled genetically in the silkworm, environmental conditions like photoperiod, temperature, humidity etc., are known to influence during the entire life cycle of the silkworm [3]. Thiadiazoles are heterocyclic compounds containing oxygen and nitrogen. 1,3,4, thiadiazoles are extensively studied and are known to play diverse biological activities [4-5]. Diamines or polyamines are found in various biological fluids and are necessary for optimal growth, replication and metabolism of every cell in the body. This research work describes the synthesis of diamino substituted thiadiazole and its effect on the growth parameters of Bombyx mori silkworm [6-8]. Diamine incorporated thiadiazoles proves as growth enhancers of $B$. mori larval weights, silk gland weights, cocoon weights in comparison with the control worms.

Therefore, the present study was taken to determine the effects of thiadiazole on the larval development and silk production of $\mathrm{CSR} 2 \times \mathrm{CSR} 4$ silkworm larvae at constant temperature $\left(25^{\circ} \mathrm{C}\right)$ and humidity $(75-80 \%)$.

\section{Material AND MethodS}

Study Area

Present work was carried out at Government Resham Kendra, Indore region (Mhow and Sonkatch) (M.P.)

\section{Experimental Species}

Productive bivoltine silkworm hybrid $(\mathrm{CSR} 2 \times$ CSR4) is obtained from Central Sericulture Research and Training Institute (Mysore, India) was used as a study material. This hybrid is suitable to rear during favourable season (August-February).

\section{Rearing method}

Bombyx mori larvae $\left(\mathrm{CSR} 2 \times \mathrm{CSR} 4\right.$ strain) were reared in laboratory conditions under constant temperature $\left(25^{\circ} \mathrm{C}\right)$ and relative humidity $(75-80 \%)$. 


\section{Dietary supplementation of the silkworm with the thiadiazole}

Bombyx mori larvae were grown on normal mulberry leaves till the end of the $4^{\text {th }}$ instar larval stage. Feeding was given from day one of the 5th instar stage as silk glands develop from 5th instar stage. Larvae were divided into two groups, each group consisting of 50 worms, one group is experimental and other is control. $1 \mathrm{mg} / \mathrm{ml}$ of the compound is dissolved in $1 \mathrm{ml}$ of ethanol. Fresh mulberry leaves were treated with the synthesized compound by swab method. These treated leaves are fed to larvae three times per day. This treatment was carried out on all the days of fifth instar. The larvae fed with plain mulberry leaves were maintained as a control group.

\section{RESULTS}

\section{(i) Estimation of growth parameters:}

Weight analysis of drug treated worms and control at $5^{\text {th }}$ instar larval stage: In the present investigation the result analysis of the effect of thiadiazole on larval weights showed positive effect. Maximum larval weight of $\mathbf{2 . 8}$ gms was observed with thiadiazole treated mulberry leaf on the $6^{\text {th }}$ day of $5^{\text {th }}$ instar larval stage and larval weight of $\mathbf{2 . 3}$ gms was observed with control (fresh mulberry leaf) on the $6^{\text {th }}$ day of $5^{\text {th }}$ instar larval stage. Thiadiazole treated larvae entered spinning stage prior to control larvae. It is summarized in table 1 and figure 1.

Table-1: Weight analysis of drug treated worms and control at $5^{\text {th }}$ instar larval stage:

\begin{tabular}{|c|c|c|c|c|c|}
\hline Larvae & $\begin{array}{l}\text { Temperature } \\
\left({ }^{\circ} \mathrm{C}\right)\end{array}$ & \begin{tabular}{|l} 
Humidity \\
(RH \%)
\end{tabular} & Treatment & Day's of $5^{\text {th }}$ instar & $\begin{array}{l}\text { Weight of larvae } \\
\text { (grams) }\end{array}$ \\
\hline \multirow{6}{*}{50} & \multirow{6}{*}{$25^{\circ} \mathrm{C}$} & \multirow{6}{*}{$75-80 \%$} & \multirow{6}{*}{ Thiadiazole Treated } & 1 & $0.7 \pm 0.40$ \\
\hline & & & & 2 & $1.2 \pm 2.510$ \\
\hline & & & & 3 & $1.6 \pm 1.502$ \\
\hline & & & & 4 & $2.2 \pm 0.20$ \\
\hline & & & & 5 & $2.3 \pm 1.324$ \\
\hline & & & & 6 & $2.8 \pm 0.201$ \\
\hline \multirow{6}{*}{50} & \multirow{6}{*}{$25^{\circ} \mathrm{C}$} & \multirow{6}{*}{$75-80 \%$} & \multirow{6}{*}{ Control } & 1 & $0.8 \pm 1.409$ \\
\hline & & & & 2 & $1.2 \pm 1.4$ \\
\hline & & & & 3 & $1.6 \pm 0.11$ \\
\hline & & & & 4 & $2.0 \pm 0.209$ \\
\hline & & & & 5 & $2.1 \pm 0.3$ \\
\hline & & & & 6 & $2.3 \pm 0.01$ \\
\hline
\end{tabular}

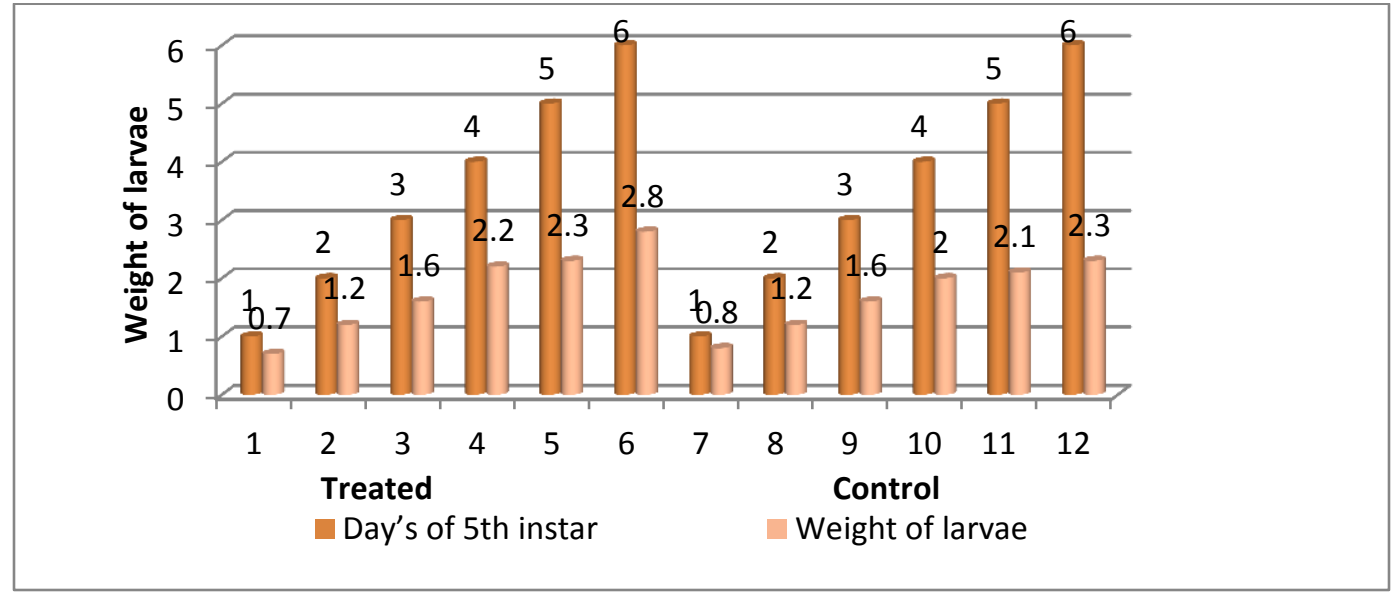

Figure-1: Weight analysis of drug treated worms and control at $5^{\text {th }}$ instar larval stage. 


\section{Length analysis of thiadiazole treated worms and control at $5^{\text {th }}$ instar larval stage:}

Effect of thiadiazole on length of worms is summarized in table 2 and figure 2. Treatment with thiadiazole resulted in the maximum larval length was $6.03 \mathbf{~ c m s}$ on $6^{\text {th }}$ day of $5^{\text {th }}$ instar larval stage and minimum larval weight of 4.00 cms on $1^{\text {th }}$ day of $5^{\text {th }}$ instar larval stage at optimum temperature and relative humidity i.e. $25^{\circ} \mathrm{C}$ and $75-80 \%$ whereas $\mathbf{5 . 0 2}$ $\mathbf{~ m s ~ o n ~} 6^{\text {th }}$ day of $5^{\text {th }}$ instar larval stage and minimum larval weight of $\mathbf{3 . 8} \mathbf{~ c m s}$ on $1^{\text {th }}$ day of $5^{\text {th }}$ instar larval stage at optimum temperature and relative humidity $\left(25^{\circ} \mathrm{C}\right.$ and $\left.75-80 \%\right)$ in control condition.

Table-2: Length analysis of thiadiazole treated worms and control at $5^{\text {th }}$ instar larval stage:

\begin{tabular}{|c|c|c|c|c|c|}
\hline Larvae & \begin{tabular}{|l} 
Temperature \\
$\left({ }^{\circ} \mathrm{C}\right)$
\end{tabular} & $\begin{array}{l}\text { Humidity } \\
(\text { RH \%) }\end{array}$ & Treatments & $\begin{array}{l}\text { Day's of } \\
5^{\text {th }} \text { instar }\end{array}$ & $\begin{array}{l}\text { Length of larvae } \\
(\mathrm{cm})\end{array}$ \\
\hline \multirow[t]{6}{*}{50} & \multirow[t]{6}{*}{$25^{\circ} \mathrm{C}$} & \multirow[t]{6}{*}{$75-80 \%$} & \multirow{6}{*}{$\begin{array}{l}\text { Thiadiazole } \\
\text { Treated }\end{array}$} & 1 & $4.00 \pm 0.31$ \\
\hline & & & & 2 & $4.9 \pm 1.01$ \\
\hline & & & & 3 & $5.3 \pm 0.782$ \\
\hline & & & & 4 & $5.5 \pm 0.40$ \\
\hline & & & & 5 & $6.00 \pm 0.371$ \\
\hline & & & & 6 & $6.03 \pm 0.230$ \\
\hline \multirow[t]{6}{*}{50} & \multirow[t]{6}{*}{$25^{\circ} \mathrm{C}$} & \multirow[t]{6}{*}{$75-80 \%$} & \multirow[t]{6}{*}{ Control } & 1 & $3.8 \pm 0.929$ \\
\hline & & & & 2 & $4.00 \pm 1.43$ \\
\hline & & & & 3 & $4.8 \pm 1.329$ \\
\hline & & & & 4 & $4.9 \pm 0.498$ \\
\hline & & & & 5 & $5.00 \pm 2.01$ \\
\hline & & & & 6 & $5.02 \pm 1.528$ \\
\hline
\end{tabular}

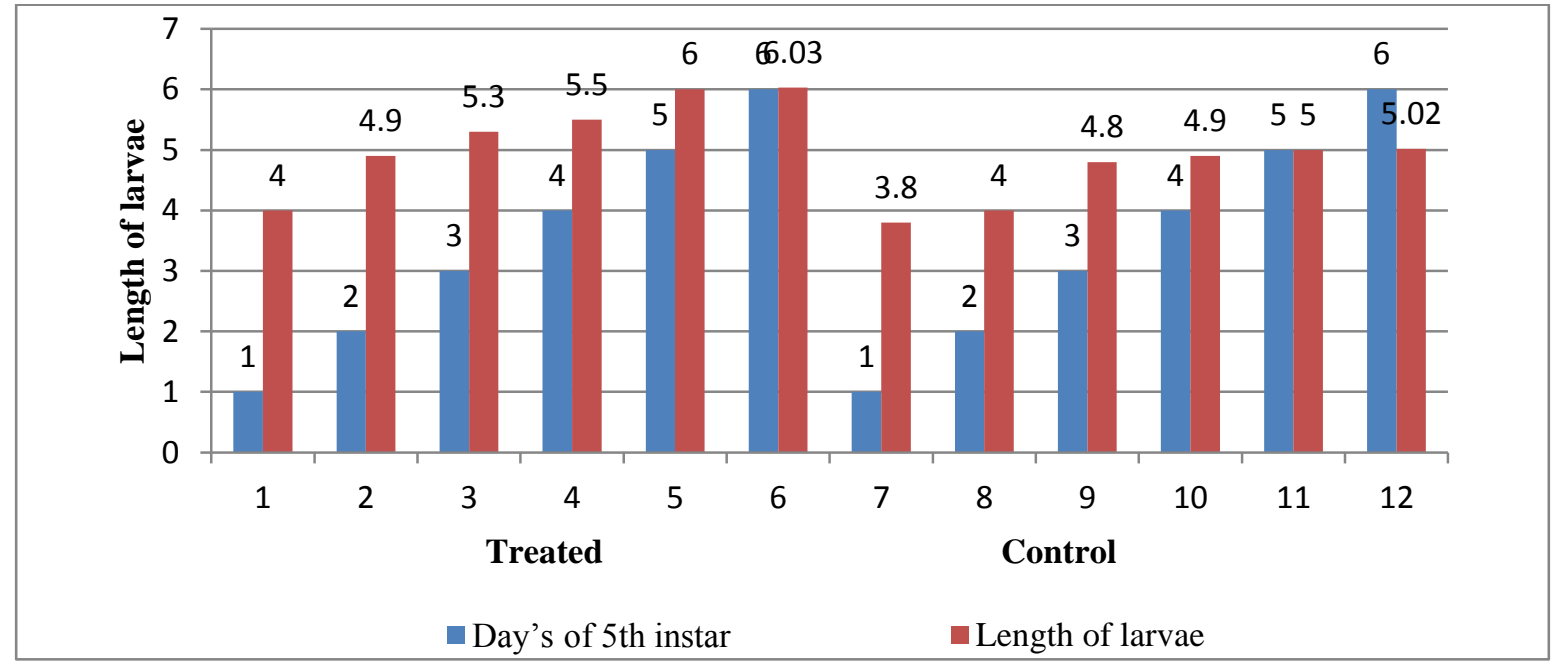

Figure-2: Length analysis of thiadiazole treated worms and control at $5^{\text {th }}$ instar larval stage.

Analysis of silk gland weights in thiadiazole treated worms and control at $5^{\text {th }}$ instar silkworms:

Effect of thiadiazole on silk glands weight is summarized in table 3 and figure 3 . Larvae treated with the thiadiazole showed better gland weight. Maximum weight gain of the silk glands was observed on the $6^{\text {th }}$ day with thiadiazole treated mulberry leaf of $\mathbf{0 . 8} \mathbf{~ g m s}$ and minimum silk gland weight of $\mathbf{0 . 1} \mathbf{~ g m s}$ on $2^{\text {nd }}$ day of the $5^{\text {th }}$ instar larvae with thiadiazole treated mulberry leaf 
at optimum temperature and humidity. In control group $\mathbf{0 . 5}$ gms as maximum silk gland weight and $\mathbf{0 . 0}$ gms as minimum silk gland weight was at optimum temperature and humidity.

Table-3: Analysis of silk gland weights in thiadiazole treated worms and control at $5^{\text {th }}$ instar silkworms:

\begin{tabular}{|c|c|c|c|c|c|}
\hline Larvae & $\begin{array}{l}\text { Temperature } \\
\left({ }^{\circ} \mathrm{C}\right)\end{array}$ & $\begin{array}{l}\text { Humidity } \\
\text { (RH \%) }\end{array}$ & Treatment & $\begin{array}{l}\text { Day's of } 5^{\text {th }} \\
\text { instar }\end{array}$ & $\begin{array}{l}\text { Silk Gland } \\
\text { Weight } \\
\text { (grams) }\end{array}$ \\
\hline \multirow{3}{*}{50} & \multirow{3}{*}{$25^{\circ} \mathrm{C}$} & \multirow{3}{*}{$75-80 \%$} & \multirow{3}{*}{$\begin{array}{l}\text { Thiadiazole } \\
\text { Treated }\end{array}$} & 2 & $0.1 \pm 0.581$ \\
\hline & & & & 4 & $0.5 \pm 0.542$ \\
\hline & & & & 6 & $0.8 \pm 0.21$ \\
\hline \multirow{3}{*}{50} & \multirow{3}{*}{$25^{\circ} \mathrm{C}$} & \multirow{3}{*}{$75-80 \%$} & \multirow{3}{*}{ Control } & 2 & $0.0 \pm 1.89$ \\
\hline & & & & 4 & $0.2 \pm 1.30$ \\
\hline & & & & 6 & $0.5 \pm 0.520$ \\
\hline
\end{tabular}

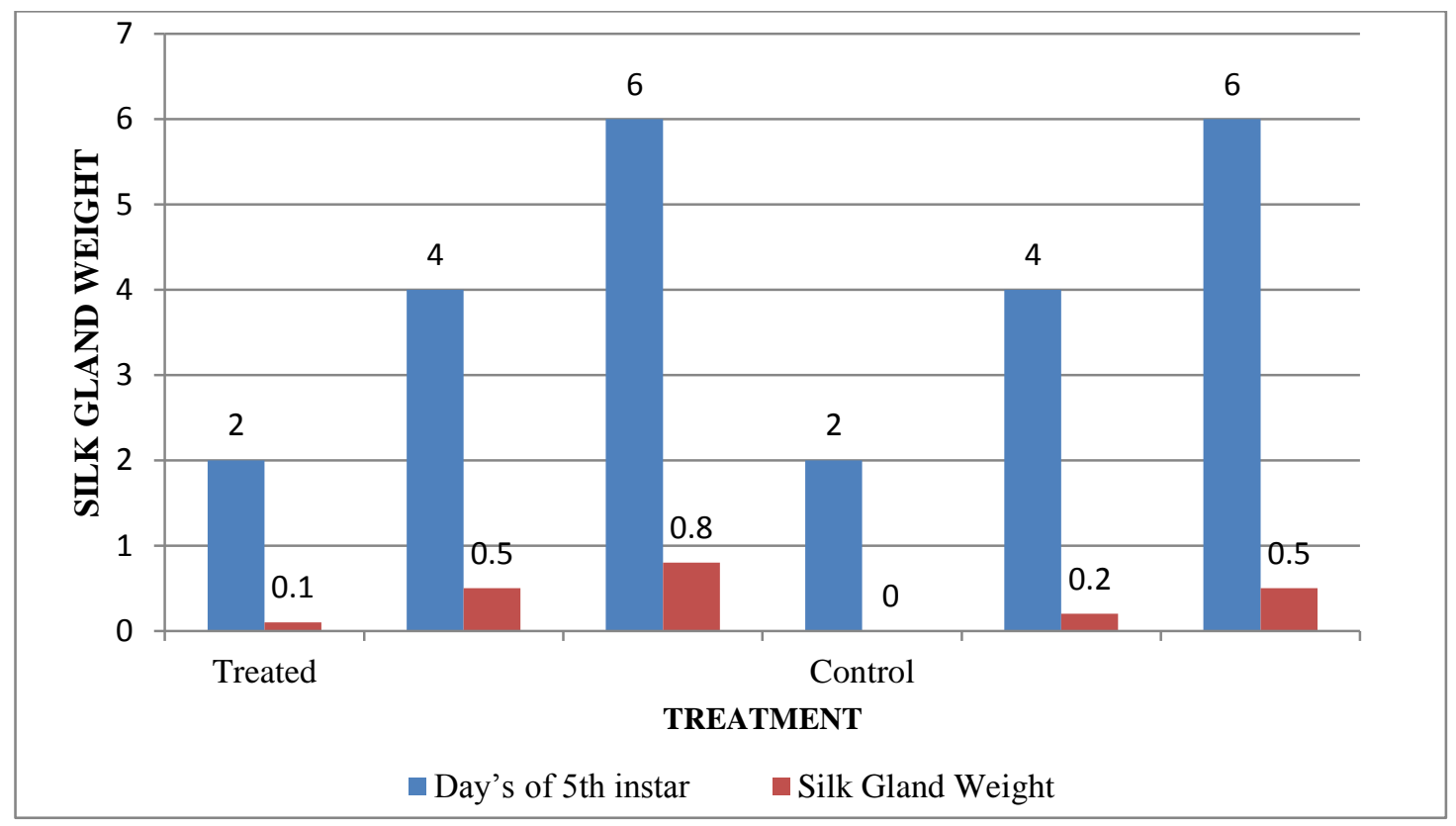

Figure-3: Analysis of silk gland weights in thiadiazole treated worms and control in $5^{\text {th }}$ instar silkworms.

\section{(ii) Evaluation of Economic parameters in thiadiazole treated worms and control:}

\section{Cocoon weight:}

Effect of thiadiazole on Cocoon weights is summarized in table 4 and figure 4. The maximum cocoon weight was found to be 3.5 gms with thiadiazole treated mulberry leaf at optimum temperature and humidity. Cocoon weight of control was $\mathbf{2 . 5}$ gms at optimum temperature and humidity.

Table-4: Evaluation of cocoon weight in thiadiazole treated worms and control:

\begin{tabular}{|l|l|l|l|l|}
\hline Larvae & Temperature & Humidity & Treatment & Cocoon weight (grams) \\
\hline 50 & $25^{\circ} \mathrm{C}$ & $75-80 \%$ & Thiadiazole Treated & $\mathbf{3 . 5} \pm \mathbf{0 . 5 9}$ \\
\hline 50 & $25^{\circ} \mathrm{C}$ & $75-80 \%$ & Control & $\mathbf{2 . 5} \pm \mathbf{0 . 3 0 0}$ \\
\hline
\end{tabular}




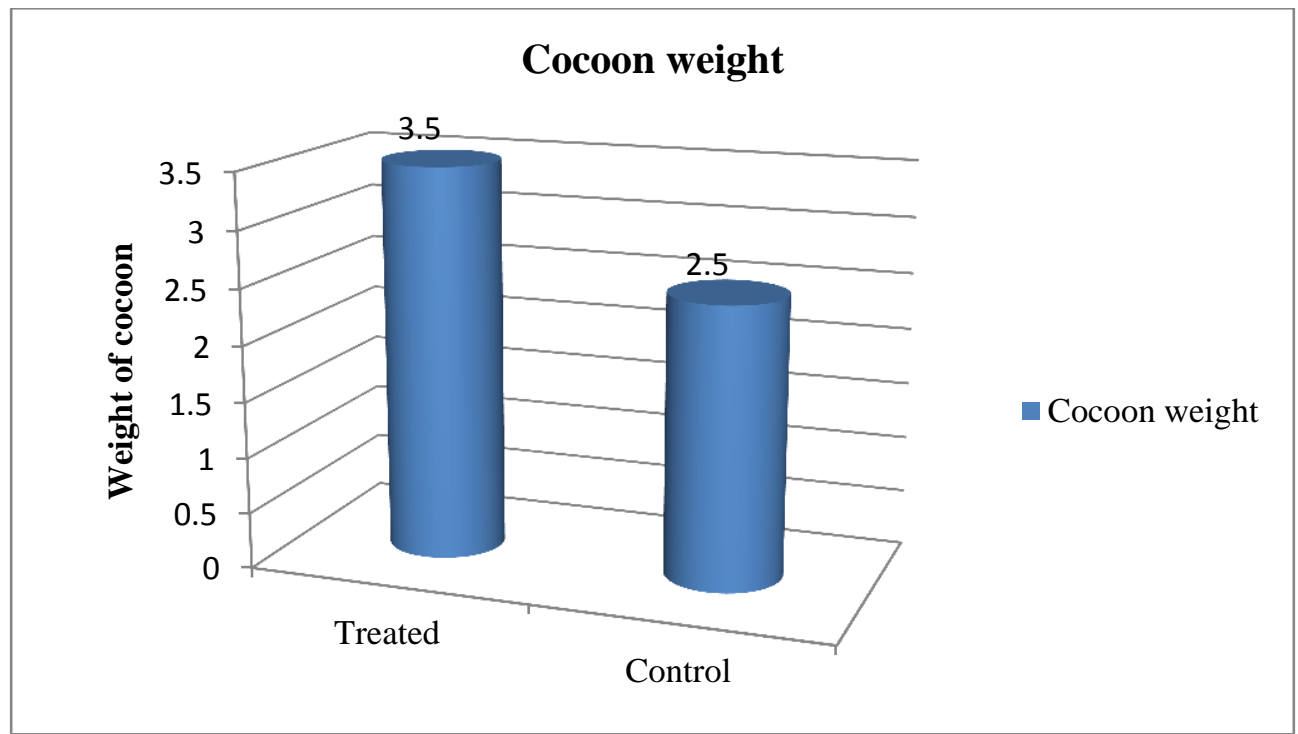

Figure-4: Evaluation of cocoon weight in thiadiazole treated worms and control.

\section{Length of silk produced:}

Effect of thiadiazole on silk production is summarized in table 5 and figure 5. The maximum amount of silk produced was 1100 meters with thiadiazole treated mulberry leaf at optimum temperature $\left(25^{\circ} \mathrm{C}\right)$ and relative humidity $(75-80 \%)$ and 702.5 meters with fresh mulberry leaf respectively at optimum temperature $\left(25^{\circ} \mathrm{C}\right)$ and relative humidity $(75-80 \%)$.

Table-5: Effect of thiadiazole on productivity of silk (at temperature $25^{\circ} \mathrm{C}$ and humidity $75-80 \%$ ):

\begin{tabular}{|l|l|l|}
\hline Larvae & Treatment & Length of silk produced (meters) \\
\hline 50 & Thiadiazole Treated & $\mathbf{1 1 0 0} \pm \mathbf{0 . 5 9 2}$ \\
\hline 50 & Control & $\mathbf{7 0 2 . 5} \pm \mathbf{1 . 3 2 0}$ \\
\hline
\end{tabular}

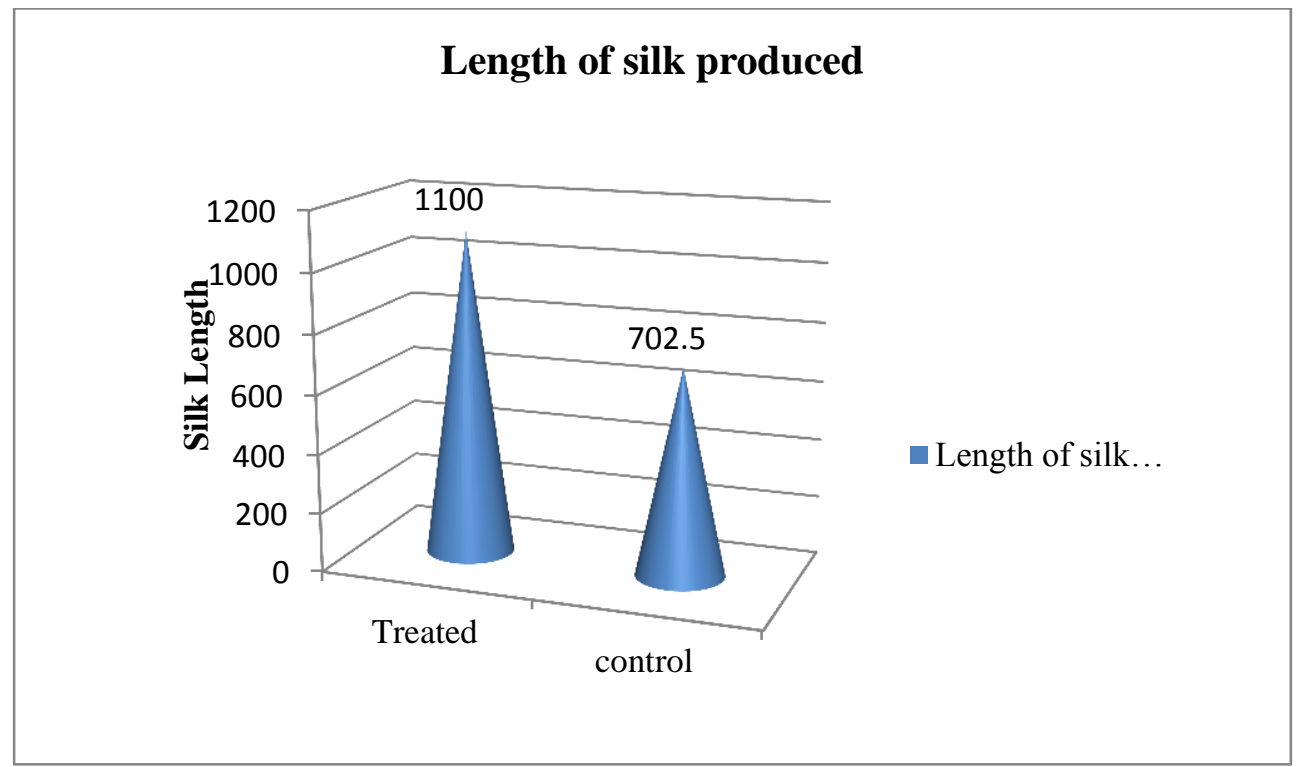

Figure-5: Effect of thiadiazole on productivity of silk (at temperature $25^{\circ} \mathrm{C}$ and humidity $75-80 \%$ ). 


\section{DiscuSSION}

The rearing of mulberry silkworm $B$. mori, which produces mulberry silk, is of great economic importance. Numerous efforts have been made to enhance its growth by several biotechnological methods. Although thiadiazole is known to have a positive effect on the growth of various organisms [9], its effect on the growth of the economically important mulberry silkworm $B$. mori was not ascertained.

In the present investigation effect of thiadiazole on the larval weight, larval length, silk gland weight, cocoon weight and length of silk produced is determine. Treatment with thiadiazole resulted in the maximum larval weight, larval length, silk gland weight, cocoon weight and length of silk produced i.e. $2.8 \mathrm{gm}, 6.03 \mathrm{~cm}, 0.8 \mathrm{gm}, 3.5 \mathrm{gm}$ and 1100 meters on $6^{\text {th }}$ day of $5^{\text {th }}$ instar larval stage. The present study results show a positive effect of thiadiazole treatment on the growth and economic parameters of mulberry silkworm.

[10] Synthesized diamino substituted thiadiazole compound and studied its effect on the various growth parameters of Bombyx mori silkworms. [11] Determined the effect of food supplementation with thiadiazole on feed efficacy of Bombyx mori. This aspect is supported by our results which show that the thiadiazole treated larvae recorded higher larval weight, larval length, silk gland weight, cocoon weight and silk length in silkworm.

From the present study, it can be interpreted that thiadiazole can be given as an extra supplement for the better growth of silkworms. The present study shows the effect of thiadiazole on the growth parameters of mulberry silkworm $B$. mori.

Present study shows the effect of diamino substituted thiadiazole on the growth of Bombyx mori silkworms. We observed an increase in the growth of B.mori silkworm when their diet is supplemented with amino substituted thiadiazole. Diamine incorporated thiadiazoles proved as growth enhancers of $B$. mori larval weights, silk gland weights, cocoon weights and viability with thiadiazole in comparison with the control worms.

\section{Conclusion}

In this experiment we have feeded the silkworm larvae with thiadiazole treated mulberry leaves. Through this experiment we have seen the significant changes in the efficiency of the larvae and cocoon of the silkworm Bombyx mori. The results of our study suggest to feed silkworm larvae with mulberry leaves treated with thiadiazole at fifth instar for better larval weight and reeling performances.

\section{BIBLIOGRAPHY}

[1] Y. Ahsan, "Variability of some quantitative traits in the hybrids silkworm, Bombyx mori", Journal of Sericultural Sciences, Japan, vol. 18, no. 5, pp. 299-301, 2006.

[2] O. Itushi, "Silkworm nutrition on mulberry plantation in Tokyo", J. seric.sci, Jpn; vol. 48, no. 8, pp. 282- $286,2012$.

[3] A. Biram and H. Gowda, "Silkworm seed technology". In Appropriate sericulture technique Central Silk Board, Bangalore, India, vol. 89, no. 4, pp. $590-599,2009$.

[4] H. Akai, K. Kiguchi and K. Mori, "Increased accumulation of silk protein accompanies KJH-induced prolongation of larval life in Bombyx mori L". Applied Entomology and Zoology, vol. 67, pp. 218-220, 1971.

[5] H. Akai, K. Kiguchi and K. Mori, "Influence of thiadiazole on the growth and metamorphosis of Bombyx larvae". Bulletin of the Sericultural Experiment Station of Japan, vol. 32, pp. 287-305, 1973.

[6] H. Akai and K. Kiguchi, "Ultrastructural changes of the posterior silk gland cells from the allata-ectomized 4th-instar larvae of Bombyx mori”. Bulletin of the Sericultural Experiment Station of Japan, vol. 28, pp. 1-14, 1981.

[7] H. Akai, K. Kiguchi, Y. Kobari and A. Shibukawa, "Practical utilization of juvenoids for increasing silk production". Scientific Papers of the Institute of Organic Physical Chemistry, vol. 22, pp. 781-792, 1981.

[8] H. Akai, K. Kimura, M. Kiuchi and A. Shibukawa, "Effects of anti-juvenoid treatment on cocoon and cocoon filaments in Bombyx mori". Journal of Sericultural Science of Japan, vol. 53, pp. 545-546, 1984.

[9] L. Cappellozza, P. Ianne and S. Cappellozza, "Effect of body weight on effectiveness of the insect growth regulator (I.G.R.) thiadiazole applied to the male and female silkworm (Bombyx mori) (Lepidoptera: Bombycidae)". Sericologia, vol. 37, pp. 443-452, 1997.

[10] C.F. Chang, S. Murakoshi and S. Tamura, "Giant cocoon formation in the silkworm, Bombyx mori L. topically treated with methylenedioxyphenyl derivates”. Agricultural Biology and Chemistry, vol. 36, pp. 629-694, 1972

[11] S.K. Chowdhary, F. Sehnal, S.K. Raj, P.S. Raju and S. Mathu, "Giant cocoon formation in Bombyx mori L. topically treated with juvenile hormone". SJ-42-F. Sericologia, vol. 26, pp. 455-457, 1986. 